\title{
Bladder Malignant PEComa
}

National Cancer Institute

\section{Source}

National Cancer Institute. Bladder Malignant PEComa. NCI Thesaurus. Code C159677.

A malignant perivascular epithelioid cell tumor arising from the bladder. 